https://doi.org/10.46344/JBINO.2021.v010i01.28

\title{
CANCER: EFFECT OF CHEMOTHERAPEUTIC AGENTS ON DSC3 EXPRESSION
}

\author{
Chandreshwar Shukla, ${ }^{a}$ N K Jain, $a$, Rajiv Modi, ${ }^{b}$, Bakulesh Khamar ${ }^{b^{*}}$ \\ a Gujarat University, Ahmedabad, Gujarat, India; \\ b Cadila Pharmaceuticals Limited, Ahmedabad, Gujarat, India \\ E-mail: $\underline{b m k @ c a d i l a p h a r m a . c o . i n ~}$
}

\begin{abstract}
DSC3 is a transmembrane cell adhesion protein. In carcinomas, DSC3 is either upregulated with its distribution as membrane and cytoplasmic protein or downregulated with undetectable DSC3 expression. The chemotherapeutic agent viz. gemcitabine, paclitaxel, cisplatin and doxorubicin known to induce the expression of cell adhesion molecules in cancer cells. We report the expression of DSC3 affected by these drugs in cancer cell lines originated from pancreatic cancer, lung cancer, melanoma and kidney fibroblast. At sub-therapeutic doses, all the DSC3 negative cell lines expressed DSC3 before death. In DSC3 positive cell lines, DSC3 conversion was less common. The conversion in DSC3 expression found variable with each drug and cell line evaluated. During drug treatment, we have observed localized expression of DSC3. For DSC3 negative cell lines membrane and cytoplasm are early to become DSC3 positive compared to nucleus; however, for DSC3 positive cell lines, nuclear negative DSC3 first observed in drug treated cells. The conversion of DSC3 in live cells is reversible in native condition. This study emphasize the status of DSC3 during chemotherapeutic drug treatment is crucial for resistance and can be an ideal target for combined therapies.
\end{abstract}

Keywords: Cancer, DSC3 expression, chemotherapeutic drug 


\section{Introduction:}

Desmocollin 3 (DSC3) is an extracellular component of Desmosome. Calciumdependent trans-membrane,

glycoprotein that belongs to the cadherin super family (Chen et al., 2012). DSC3 is one of the desmosome adhesion molecule and is major adhesive force of epithelial cells (Garrod \& Chidgey, 2008; Wheelock et al., 2001). In normal epithelium, DSC3 is known to be expressed as a membrane protein (Waschke 2008) and seen mainly in suprabasal layer of stratified epithelium, like tongue, tonsil, oesophagus, bladder, vagina etc (Uhlen et al., 2010). In rapidly dividing cells, it is present in cytoplasm also (Den et al., 2006). Its expression reported in various cancer (Chidgey and Dawson 2007). Desmocollins are integral membrane proteins, synthesized on ERbound ribosomes (Magali et al., 2014). Loss of DSC3 expression contributes to the paucity of adhesion as seen in blistering skin disorders (Ayub et al., 2009).

During carcinogenesis DSC3 is either upregulated with its distribution as membrane and cytoplasmic protein or downregulated with undetectable DSC3 expression ( $M$ Chidgey and $C$ Dawson 2007). On basis of DSC3 expression, epithelial cancer can be broadly categorized in two subsets, one where DSC3 is over expressed such as in squamous NSCLC (Valentina et al., 2009; Tsuta et al., 2011) colorectal cancer (Cui et al 2011) and skin cancer (Jiangli et al., 2012; Rezze et al., 2011); others where DSC3 is expression is absent such as breast (Oshiro et al., 2005) and prostate cancer (Pan et al., 2014).

DSC3 is a P53 regulated gene. P53 target the DSC3 promoter region, which stimulate histone acetylation at the binding site to increase the accessibility of the DSC3 gene (Cui T et al., 2011).

Loss of DSC 3 expression is associated with low calcium levels, mutation/inhibition of SERCA pump (Magali $S$ et al., 2014), mutation or hypermethylation of p53 (Oshiro et al., 2003) or its degradation (Jörg Weiske et al., 2001). Correction of alteration by appropriate agents results in expression of DSC3.

Chemotherapeutic drugs like Doxorubicin (T Cui et al 2011), Cisplatin (Xiaobing et al., 2011), Gemicitabine (Buranrat et al., 2010) and Paclitaxel (Giannakakou et al., 2001) are known to increase p53 expression and some of them are known to upregulate DSC3 expression in DSC3 negative cancers (Krunal et. al., 2019). However their effect on DSC3 expressing cancer cells is not described. There is no information on dose response as well as duration of treatment with these agents. We planned this study to evaluate the expression of DSC3 in various cancer and changes in expression of this adhesion molecule as result of chemotherapeutic drug treatment.

\section{MATERIALS AND METHODS}

\section{Cell lines and cell culture}

Pancreatic cells (SW1990, Panc-1, AsPC-1 and Mia-Pa-Ca2), Lung cancer cells (L132, A549), Colorectal cancer cells HCT15, HT-29), Mouse skin melanoma (B16F1 and B16F10) and Monkey kidney fibroblast cells (Cos7) were purchased from either American Type Culture Collection (ATCC Rockville, MD, USA) or National Centre for Cell Science, Pune (NCCS). SW1990, Panc-1, AsPc-1, Mia-PaCa2, L132, HCT15, HT29, B16F1, B16F10 and Cos7 cells were cultured in 
Dulbecco's Modified Eagles Medium (DMEM) supplemented with $10 \%$ FBS and maintained in a humidified atmosphere with $5 \% \mathrm{CO}_{2}$ at $37^{\circ} \mathrm{C}$. A549 cells were cultured in HAM's medium supplemented with $10 \%$ FBS and maintained in a humidified atmosphere with $5 \% \mathrm{CO}_{2}$ at $37^{\circ} \mathrm{C}$.

\section{Drugs used for treatment of cells}

Cisplatin (Platin injection $10 \mathrm{mg}$, from Cadila pharmaceuticals), Paclitaxel (Paclicad injection $30 \mathrm{mg}$, from Cadila pharmaceuticals), Doxorubicine (Cadria $50 \mathrm{mg}$, from cadila pharmaceuticals), Gemcitabine (Tabicad 200 mg, from Cadila Pharmaceuticals). Paclitaxel, Gemcitabine reconstituted in physiological saline were as Doxorubicine reconstituted in sterile WFI.

\section{Drug treatment}

All cells were cultured in T-75 flasks. Cells were harvested at $70 \%$ confluence. $1 \times 10^{5}$ cells were plated in each well of 12 well plates. Doxorubicine was added at final concentration of $5 \mu \mathrm{M}, 10 \mu \mathrm{M}$ and 20 $\mu M$, Cisplatin was added at final concentration of $5 \mu \mathrm{g}, 10 \mu \mathrm{g}$ and $20 \mu \mathrm{g}$, Paclitaxel was added at final concentration of $2.5 \mu \mathrm{g}, 5 \mu \mathrm{g}$ and $10 \mu \mathrm{g}$, Gemcitabine was added at final concentration of $1.25 \mu \mathrm{M}, 2.5 \mu \mathrm{M}$ and 5 $\mu \mathrm{M}$. The drug concentration of these drugs selected on basis of previous experiences with these drugs (Krunal et. al., 2019). All drugs were diluted in culture media. Plates were incubated for 24 hours, before harvesting the cells for DSC 3 expression. The cells were reseeded in fresh growth medium post drug treatment.

\section{Immunohistochemistry (IHC)}

Smears of the cancer cells were prepared onto the tissue culture slides and subjected to the air drying; the fixation was done with chilled methanol for 30 minutes. After fixation the slides were washed three times with PBS. For blocking slides were treated with blocking solution (5\% BSA, $2 \%$ serum, $2 \%$ tritonX100) for 1 hours. The cells further incubated for 1 hours at room temperature with Mouse Monoclonal anti-desmocollin 3 (Abcam-Ab55011) antibody. Detection was done with HRP conjugated antibody (Goat anti Mouse IgG-HRP, Genei). The slides were counter stained with $0.5 \%$ Methyl green for five minutes. All slides were read by two different Scientist. IHC was scored as Cytoplasm, Membrane and Nuclear positive or negative.

\section{RESULTS}

\section{DSC3 Expression analysis in different cancer cell lines}

DSC3 expression was seen (DSC3 +ve) in colorectal (HCT15, HT29), melanoma (B16F1, B16F10) as well as squamous NSCLC (L132) cell lines evaluated. It was present in one (SW1990) of four pancreatic cancer cell lines evaluated, it was absent (DSC3-ve) in three of four pancreatic, Adenocarcinoma of lung and control kidney cell line. (Table-1) The p53 status of each cell line reveals 4 of 5 of the DSC3 negative cell lines to harbor mutant p53 while 5 of six cell lines expressing wild type p53. 
Table-1: Cell lines and p53 status

\begin{tabular}{|c|c|c|c|c|}
\hline $\begin{array}{l}\text { Sr. } \\
\text { No. }\end{array}$ & Cell Line & Cancer Type & P53 Status & DSC3 Status \\
\hline 1 & SW1990 & Human Pancreatic & Wild type (Wu et al., 2019) & Positive \\
\hline 2 & Panc- 1 & Human Pancreatic & Mutant (Wu et al., 2019) & Negative \\
\hline 3 & AsPc -1 & Human Pancreatic & Mutant (Butz et al., 2003) & Negative \\
\hline 4 & Mia-Pa-Ca2 & Human Pancreatic & Mutant (Fiorini et al., 2015) & Negative \\
\hline 5 & HCT 15 & $\begin{array}{l}\text { Human colorectal } \\
\text { Adenocarcinoma }\end{array}$ & Mutant (Leroy et al., 2004) & Positive \\
\hline 6 & HT-29 & $\begin{array}{l}\text { Human colorectal } \\
\text { Adenocarcinoma }\end{array}$ & $\begin{array}{l}\text { Mutant (Barberi-Heyob et al., } \\
\text { 2004) }\end{array}$ & Positive \\
\hline 7 & L-132 & $\begin{array}{l}\text { Human Non-small cell } \\
\text { lung cancer } \\
\text { (Squamous NSCLC) }\end{array}$ & Wild type (Takeyama et al., 2004) & Positive \\
\hline 8 & A549 & $\begin{array}{l}\text { Human Non sma; } \\
\text { cell lung cancer } \\
\text { (Adenocarcinoma) }\end{array}$ & Wild type (Margarita et al., 2020) & Negative \\
\hline 9 & B16 F1 & Mouse skin melanoma & $\begin{array}{l}\text { Wild type (Melnikova et al., } \\
\text { 2004) }\end{array}$ & Positive \\
\hline 10 & B16 F10 & Mouse skin melanoma & $\begin{array}{l}\text { Wild type (Melnikova et al., } \\
\text { 2004) }\end{array}$ & Positive \\
\hline 11 & $\operatorname{Cos} 7$ & $\begin{array}{l}\text { Monkey kidney } \\
\text { fibroblast }\end{array}$ & Wild type (Mulloy et al., 1998) & Negative \\
\hline
\end{tabular}

\section{Expression analysis of DSC3 in different cancer cell lines after chemotherapeutic drug treatment}

Immunohistochemistry analysis of different cell lines post treatment with chemotherapeutic drugs at human therapeutic and sub-therapeutic dose, revealed DSC3 expression was changed post treatment (Table-2). 
Table-2: Expression analysis of DSC3 in different cancer cell lines after drug treatment at therapeutic and sub-therapeutic dose.

\begin{tabular}{|c|c|c|c|c|c|c|c|c|c|c|c|c|c|}
\hline \multirow[b]{2}{*}{ Cell Lines } & \multirow[b]{2}{*}{ 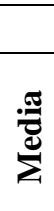 } & \multicolumn{3}{|c|}{ Cisplatin } & \multicolumn{3}{|c|}{ Paclitaxel } & \multicolumn{3}{|c|}{ Gemcitabine } & \multicolumn{3}{|c|}{ Doxorubicin } \\
\hline & & 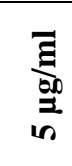 & $\begin{array}{l}\bar{E} \\
\hat{z} \\
\hat{\theta} \\
e\end{array}$ & 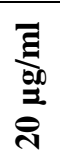 & 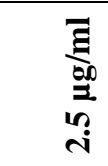 & $\begin{array}{c}\bar{E} \\
\underset{E 0}{E} \\
n\end{array}$ & స్ & 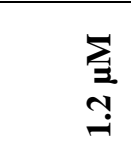 & $\underset{\substack{n \\
\text { in }}}{\sum_{3}}$ & $\sum_{10}$ & $\sum_{i}$ & $\underset{z}{\underline{E}}$ & 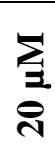 \\
\hline \multicolumn{14}{|l|}{ L-132 } \\
\hline \multicolumn{14}{|l|}{ SW1990 } \\
\hline \multicolumn{14}{|l|}{ HCT15 } \\
\hline \multicolumn{14}{|l|}{ B16 F1 } \\
\hline \multicolumn{14}{|l|}{ B16 F10 } \\
\hline \multicolumn{14}{|l|}{ HT- 29} \\
\hline \multicolumn{14}{|l|}{$\operatorname{Cos} 7$} \\
\hline \multicolumn{14}{|l|}{ Panc- 1} \\
\hline \multicolumn{14}{|l|}{ AsPc -1 } \\
\hline Mia-Pa-Ca2 & & & & & & & & & & & & 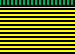 & \\
\hline A549 & & & & & & & & & & & & & \\
\hline
\end{tabular}

* The cells were reseeded in fresh growth media without drug, cells were found attached and retained its native expression of DSC3.

\begin{tabular}{|l|l|}
\hline & Live, DSC $3^{+}$ \\
Live, DSC $3^{-}$ \\
\hline
\end{tabular}

All the DSC3 negative cell lines had DSC3 conversion (DSC3 conversion; +ve to -ve or -ve to +ve) before death and at a sub-therapeutic level, however the DSC3 conversion was variable with each drug and cell line evaluated. Mia-Pa-Ca2 had DSC3 conversion with all the drugs at subtherapeutic concentration. Panc-1 and AsPc-1 were unique to undergo DSC3 conversion at a lowest dose and reconversion (DSC3-ve again) at a higher sub therapeutic dose (Table 2).

DSC3 conversion was less common in DSC3+ve cell lines. It was not seen in colorectal cancer cell lines (HCT 15, HT29) and was seen in melanoma cell lines (B16F1 and B16F10) with all four drugs evaluated (Table 2). 
Table-3: Sequence of events analysis for DSC3 expression in different cancer cell lines.

\section{A. Paclitaxel}

\begin{tabular}{|c|c|c|c|c|c|c|c|c|c|c|c|c|}
\hline & \multicolumn{3}{|c|}{$0 \mathrm{hr}$} & \multicolumn{3}{|c|}{$24 \mathrm{hr}$} & \multicolumn{3}{|c|}{$48 \mathrm{hr}$} & \multicolumn{3}{|c|}{$72 \mathrm{hr}$} \\
\hline & 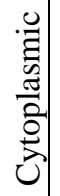 & 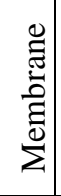 & 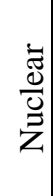 & 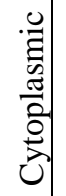 & 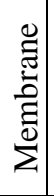 & 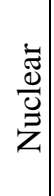 & 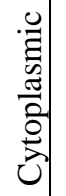 & 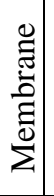 & $\begin{array}{c}\overrightarrow{\tilde{J}} \\
\frac{\mathrm{d}}{\mathrm{U}} \\
\bar{z}\end{array}$ & 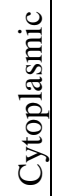 & 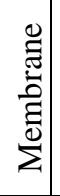 & $\frac{\frac{d}{\tilde{J}}}{\bar{z}}$ \\
\hline L132 & & & & & & & & & & & & \\
\hline SW1990 & & & & & & & & & & & & \\
\hline НCТ-15 & & & & & & & & & & & & \\
\hline $\mathrm{B} 16 \mathrm{~F} 1$ & & & & & & & & & & & & \\
\hline B16F10 & & & & & & & & & & & & \\
\hline НT29 & & & & & & & & & & & & \\
\hline Panc-1 & & & & & & & & & & & & \\
\hline AsPC-1 & & & & & & & & & & & & \\
\hline $\operatorname{Cos} 7$ & & & & & & & & & & & & \\
\hline $\mathrm{Mia}-\mathrm{Pa}-\mathrm{Ca} 2$ & & & & & & & & & & & & \\
\hline A549 & & & & & & & & & & & & \\
\hline
\end{tabular}

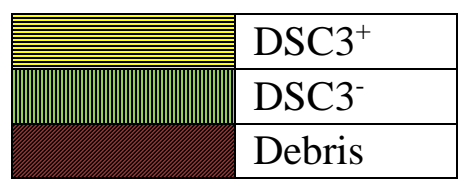

B. Cisplatin

\begin{tabular}{|c|c|c|c|c|c|c|c|c|c|c|c|c|}
\hline & \multicolumn{3}{|c|}{$0 \mathrm{hr}$} & \multicolumn{3}{|c|}{$24 \mathrm{hr}$} & \multicolumn{3}{|c|}{$48 \mathrm{hr}$} & \multicolumn{3}{|c|}{$72 \mathrm{hr}$} \\
\hline & 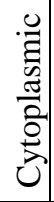 & 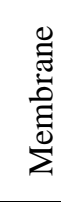 & 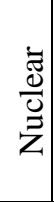 & 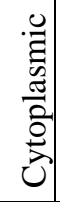 & 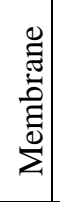 & $\frac{\vec{J}}{\frac{U}{U}}$ & 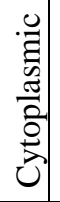 & 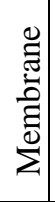 & $\begin{array}{c}\overrightarrow{\tilde{J}} \\
\frac{\mathrm{d}}{\mathrm{U}} \\
\overrightarrow{\mathrm{Z}}\end{array}$ & 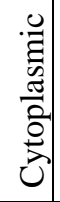 & 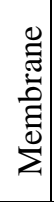 & $\begin{array}{l}\frac{\vec{z}}{\tilde{e}} \\
\vec{z}\end{array}$ \\
\hline L132 & & & & & & & & & & & & \\
\hline SW199 & & & & & & & & & & & & \\
\hline HCT-15 & & & & & & & & & & & & \\
\hline $\mathrm{B} 16 \mathrm{~F} 1$ & & & & & & & & & & & & \\
\hline B16F10 & & & & & & & & & & & & \\
\hline HT29 & & & & & & & & & & & & \\
\hline Panc-1 & & & & & & & & & & & & \\
\hline
\end{tabular}

2021 January Edition | www.jbino.com | Innovative Association 


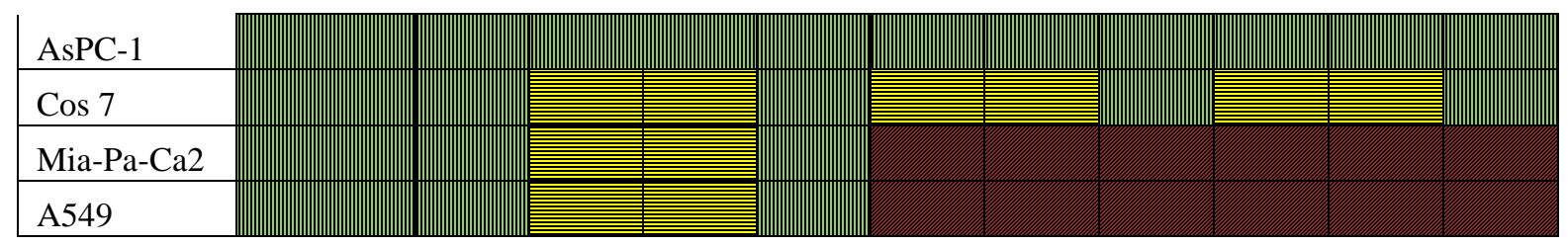

\section{Doxorubicin}

\begin{tabular}{|c|c|c|c|c|c|c|c|c|c|c|c|c|}
\hline & \multicolumn{3}{|c|}{$0 \mathrm{hr}$} & \multicolumn{3}{|c|}{$24 \mathrm{hr}$} & \multicolumn{3}{|c|}{$48 \mathrm{hr}$} & \multicolumn{3}{|c|}{$72 \mathrm{hr}$} \\
\hline & $\begin{array}{l}. \\
0 \\
0 \\
0 \\
0 \\
0 \\
0 \\
0 \\
0\end{array}$ & 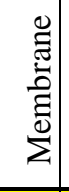 & 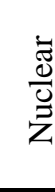 & 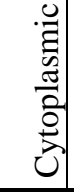 & 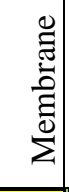 & $\begin{array}{l}\frac{\bar{v}}{n} \\
\bar{n}\end{array}$ & $\begin{array}{l}0 \\
0 \\
0 \\
0 \\
0 \\
0 \\
0 \\
0\end{array}$ & 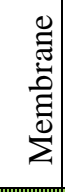 & $\begin{array}{l}\frac{\overline{5}}{\frac{D}{n}} \\
\bar{Z}\end{array}$ & 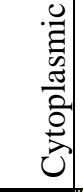 & $\begin{array}{l}\text { : } \\
\text { : } \\
\text { : } \\
\Sigma \\
\Sigma\end{array}$ & $\frac{\overline{5}}{\frac{5}{2}}$ \\
\hline L132 & & & & & & & & & & & & \\
\hline SW1990 & & & & & س. & & & & & & & \\
\hline HCT-15 & & & & & & & & & & & & \\
\hline B16F1 & & & & & & & & & & & & \\
\hline B16F10 & & & & & & & & 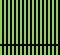 & & & 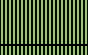 & \\
\hline HT29 & & & & & & & & $\mathbb{m}$ & & & m & \\
\hline Panc-1 & & & & & & & & 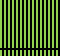 & & 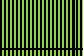 & س & \\
\hline AsPC-1 & & & & & min & & & min & & mine & mumum & \\
\hline $\operatorname{Cos} 7$ & & & & & & 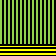 & & & & & & \\
\hline Mia-Pa-Ca2 & & & & & & & & & & & & \\
\hline A549 & & & & & & & & & & & & \\
\hline
\end{tabular}

D. Gemcitabine

\begin{tabular}{|c|c|c|c|c|c|c|c|c|c|}
\hline & \multicolumn{3}{|c|}{$0 \mathrm{hr}$} & \multicolumn{3}{|c|}{$24 \mathrm{hr}$} & \multicolumn{3}{|c|}{$48 \mathrm{hr}$} \\
\hline & 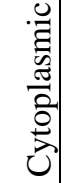 & 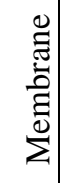 & $\frac{5}{3}$ & 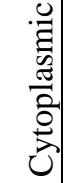 & $\begin{array}{l}\text { : } \\
\text { : } \\
\sum_{0}^{ \pm !}\end{array}$ & $\begin{array}{l}\frac{\tilde{d}}{\tilde{J}} \\
z\end{array}$ & 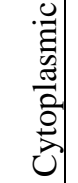 & $\begin{array}{l}\text { : } \\
\text { : } \\
\text { : } \\
\sum_{0}^{0}\end{array}$ & 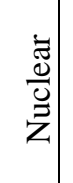 \\
\hline L132 & & & & & & & & 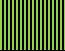 & \\
\hline SW1990 & & & & & & & & & \\
\hline HCT-15 & & & & & & & & & \\
\hline $\mathrm{B} 16 \mathrm{~F} 1$ & & & & & & & & & \\
\hline $\mathrm{B} 16 \mathrm{~F} 10$ & & & & & & & & & \\
\hline HT29 & & & & & & & Ind & 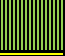 & \\
\hline Panc-1 & & & & & & & & & \\
\hline AsPC-1 & & & & & & & & & \\
\hline $\operatorname{Cos} 7$ & & & & & & & & & \\
\hline
\end{tabular}

2021 January Edition | www.jbino.com | Innovative Association 


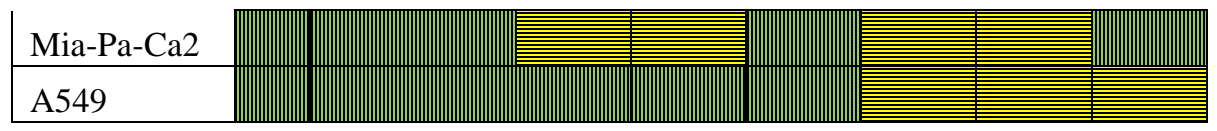

Evaluation of DSC3 conversion over time by various subcomponent reveals two distinct patterns. DSC3 conversion begins in cytoplasm and membranes in DSC3 negative cell lines while it seems to begin in nucleus in DSC3 positive cell lines. (Table3). Reconversion to original DSC3 status seen on transferring live cells to chemotherapeutic drug free culture medium. The DSC3 positive cells, which lose its DSC3 from surface and become DSC3 negative in drug treatment condition found dead and detached from the plate surface. The detached cells found dead post reseeding in fresh medium, may have initiated apoptosis process.

\section{Discussion:}

In this study, the expression of DSC3 have been analyzed in various cancer cell lines. The DSC3 expression in these cell lines is in line with previously described reports for expression of adhesion molecules in human cancer samples, for example, in NSCLC, DSC3 is expressed by squamous cell carcinoma and not by adenocarcinoma. (Valentina $M$ et al., 2009; Tsuta K et al., 2011). Melanoma and colorectal cancers are known to express DSC3 (T Cui et al 2011; Jiangli $C$ et al., 2012; Gisele Gargantini Rezze et al., 2011). DSC3 status in pancreatic cancer is not described so far. Relationship between DSC 3 expression and p53 status in this study relates previous reports of DSC3 being p53 responsive gene (CUi T. et. Al., 2011).

Adhesion molecules are known to change their expression following exposure to Cispaltin, Paclitaxel, Gemcitabine and Doxorubicin ( $\mathrm{Yu}$ et al., 2008; Raimonda et al., 2016, Duxbury et al., 2004, Cui et al., 2011). DSC3 being an adhesion molecule, conversion of DSC3 negative cell lines with chemotherapeutic agents seen in this study may be part of change in adhesion molecules. Chemotherapeutic agents are also known to increase wild type of p53 and DSC3 expression (Cui et al., 2012; Pan et al., 2014, Oshiro et al., 2005). DSC3 conversion at sub therapeutic dose and its reconversion on removal of chemotherapeutic agents is not described previously. This could be due chemotherapeutic agent induced stress on secretory pathway (endoplasmic reticulum + golgi apparatus) of cancer cells (Palam L et al., 2015). Disturbances of golgi apparatus and its fragmentation is known following chemotherapy. (Núñez-Olvera et al., 2020). Golgi apparatus known to control protein expression through E3 ligases. MDM2 is one of the E3 ligases known to suppress p53 (Sparks A et al., 2014; Gupta et al 2019). Loss of its activity may be responsible for DSC3 expression in DSC3 negative cells at a sub therapeutic level. The conversion of DSC3 in positive cancer cell lines seen in this study, which begins at perinuclear area, has not been described before. Desmocollins are known to be retained at endoplasmic reticulum under stress induced by low calcium concentration (Magali $S$ et al., 2014). The endoplasmic stress induced by chemotherapeutic agents is a plausible 
explantion for observed changes. The other possibility for loss of DSC3 expression can be activation of the metalloproteinase and subsequent shedding of extracellular domain of DSC3 (Jörg Weiske et al., 2001).

Studying effect of chemotherapeutic agents on DSC3 expression by cancer cell lines suggests different biological processes and needs further studies. It also provides guidance on better use of DSC3 targeting therapy.

\section{Reference:}

J. Chen, C. Shea, J. E. Fitzpatrick et al. Loss of Desmocollin 3 in Skin Tumor Development and Progression. Mol Carcinog. (2012) 51(7); 535-545. https://doi.org/10.1002/mc.20818.

D. Garrod, M. Chidgey, Desmosome structure, composition and function, Biochimica et Biophysica Acta (BBA) Biomembranes (2008), 1778(3); 572-587. https://doi.org/10.1016/j.bbamem.2007.0 7.014 .

\section{J. Wheelock, A. P. Soler, K. A. Knudsen.}

Cadherin junctions in mammary tumors. Journal of Mammary Gland Biol Neoplasia. (2001), 6(3); 275-85. https://doi.org/10.1023/a:1011319507155.

J. Waschke. The desmosome and pemphigus. Histochem Cell Biol. (2008), 130(1); 21-54. https://doi.org/10.1007/s00418-008-0420-0.

M. Uhlen, P. Oksvold, L. Fagerberg, E. Lundberg, K. Jonasson, $M$. Forsberg, $M$. Zwahlen, C. Kampf, K. Wester, S. Hober, H. Wernerus, L. Björling, F. Ponten. Towards a knowledge-based Human Protein Atlas,
Nat Biotechnol. (2010), 28; 1248-1250. Human Protein Atlas https://www.proteinatlas.org/ENSG000001 34762-DSC3/tissue. Accessed 26 Oct 2020.

Z. Den, X. Cheng, M. Merched-Sauvage, P.J. Koch, Desmocollin 3 is required for pre-implantation development of the mouse embryo. J Cell Sci. (2006), 119 (Pt 3):482-9. https://doi.org/doi: 10.1242/jcs.02769.

M. Chidgey and C. Dawson, Desmosomes: a role in cancer? British Journal of Cancer (2007), 96; 1783 - 1787. https://doi.org/doi/10.1038/sj.bjc.6603808.

S .Magali, S .Marina, E .Anissa, G. Laure, and $\mathbf{H}$. Alain, SERCA2 Dysfunction in Darier Disease Causes Endoplasmic Reticulum Stress and Impaired Cell-to-Cell Adhesion Strength: Rescue by Miglustat. Journal of Investigative Dermatology (2014), 134; 1961-1970; https://doi.org/doi/10.1038/jid.2014.8.

M. Ayub, S. Basit, M. Jelani, F. U. Rehman, M. Iqbal, M. Yasinzai, and W, Ahmad, A homozygous nonsense mutation in the human desmocollin-3 (DSC3) gene underlies hereditary hypotrichosis and recurrent skin vesicles. American journal of human genetics (2009), 85(4); 515-520. https://doi.org/10.1016/j.ajhg.2009.08.015

M. Valentina, C. Paolo, R. Luisella, T. Veronica, M. Tavaglione, V. Marco, P. Giuseppe, V.S. Giorgio and P. Mauro, Desmocollin-3: a new marker of squamous differentiation in undifferentiated large-cell carcinoma of the lung. Modern Pathology (2009), 22; 709-717. 
https://doi.org/10.1038/modpathol.2009.3 0 .

K. Tsuta, Y. Tanabe, A. Yoshida etal., Utility of 10 Immunohistochemical Markers Including Novel Markers (Desmocollin-3, Glypican 3, S100A2, S100A7, and Sox-2) for Differential Diagnosis of Squamous Cell Carcinoma from Adenocarcinoma of the Lung. Journal of Thoracic Oncology (2011), 6(7); 1190-1199. https://doi.org/10.1097/JTO.0b013e31821 9ac78.

T. Cui, Y. Chen, L. Yang et al., DSC3 expression is regulated by p53, and methylation of DSC3 DNA is a prognostic marker in human colorectal cancer. British Journal of Cancer (2011) 104; 10131019.

https://doi.org/doi 10.1038/bjc.2011.28.

G. G. Rezze, J. H. Tavares, G. Fregnani, J. Duprat, G. Landman Cell adhesion and communication proteins are differentially expressed in melanoma progression model. Human Pathology (2011) 42; 409418. https://doi.org/10.1186/s42047-0190034-y

MM. Oshiro, CJ. Kim, RJ. Wozniak et al., Epigenetic silencing of DSC 3 is a common event in human breast cancer. Breast Cancer Res. (2005), 7(5); 669-80. https://doi.org/10.1186/bcr1273

J. Pan, Y. Chen, C. Mo, D. Wang, J. Chen, et al., Association of DSC3 mRNA DownRegulation in Prostate Cancer with Promoter Hypermethylation and Poor Prognosis. PLOS ONE. (2014), 9(3). https://doi.org/ e92815.
MM. Oshiro, GS. Watts, RJ. Wozniak et al., Mutant p53 and aberrant cytosine methylation cooperate to silence gene expression. Oncogene. (2003), 22; 36243634. https://doi.org/ 10.1038/sj.onc. 1206545

J. Weiske, T. Schöneberg, W. Schröder et al., The Fate of Desmosomal Proteins in Apoptotic Cells. The Journal of Biological Chemistry (2001), 276; 41175-41181.

\section{Xiaobing, G. Yi, W. D. Figg, A. T. Fojo,} M.D. Mueller, J. J. Yu, "The Role of WildType p53 in Cisplatin-Induced Chk2 Phosphorylation and the Inhibition of Platinum Resistance with a Chk2 Inhibitor". Chemotherapy Research and Practice (2011), 2; 8 pages. https://doi.org/10.1155/2011/715469

\section{B. Buranrat, A. Prawan, U.} Kukongviriyapan, S. Kongpetch, V. Kukongviriyapan, Dicoumarol enhances gemcitabine-induced cytotoxicity in high NQO1-expressing cholangiocarcinoma cells. World J Gastroenterol. (2010), 16(19); 2362-70. https://doi.org/10.3748/wjg.v16.i19.2362.

P. Giannakakou, R. Robey, T. Fojo, et al., Low concentrations of paclitaxel induce cell type-dependent p53, p21 and G1/G2 arrest instead of mitotic arrest: molecular determinants of paclitaxel-induced cytotoxicity. Oncogene (2001), 20; 38063813.

https://doi.org/10.1038/sj.onc.1204487

S. Wu, H. Xu, X. Wu, P. Liu, Y. Shi, P. Pang, L. Deng, G. Zhou, $X$. Chen, Dihydrosanguinarine suppresses pancreatic cancer cells via regulation of mut-p53/WT-p53 and the Ras/Raf/Mek/Erk pathway. 
Phytomedicine. (2019) 59; 152895. https://doi.org/10.1016/j.phymed.2019.15 2895.

\section{J. Butz, E. Wickstrom, J. Edwards,} Characterization of mutations and loss of heterozygosity of p53 and K-ras2 in pancreatic cancer cell lines by immobilized polymerase chain reaction. BMC Biotechnol. (2003), 3(11). https://doi.org/doi:10.1186/1472-6750-311

C. Fiorini, M. Cordani, C. Padroni, G. Blandino, S. D. Agostino, M. Donadelli, Mutant p53 stimulates chemoresistance of pancreatic adenocarcinoma cells to gemcitabine. Biochimica et Biophysica Acta. (2015), 1853; 89-100.

B Leroy, L Girard, A Hollestelle, J D Minna, A F Gazdar, T Soussi. Analysis of TP53 Mutation Status in Human Cancer Cell Lines: A Reassessment. Hum Mutat. (2014), $35(6)$; 756-765. https://doi.org/10.1002/humu.22556.

Barberi-Heyob $M$, Védrine PO, Merlin JL, Millon R, Abecassis J, Poupon MF, Guillemin F. Wild-type p53 gene transfer into mutated p53 HT29 cells improves sensitivity to photodynamic therapy via induction of apoptosis. Int J Oncol. (2004), 24(4); 951-8.

N.Takeyama, T. Tanaka, T. Yabuki, T. Nakatani. The involvement of p53 in paraquat-induced apoptosis in human lung epithelial-like cells. Int J Toxicol. (2004) 23(1); 33-40. https://doi.org/doi: 10.1080/10915810490265432.

P. Margarita, A. Lina, S. Nadezhda, C. Anna, B. Taisia, C.N. Roman, N.O.

\section{January Edition | Www.jbino.com | Innovative Association}

Andreyan, L. Sergey, The p53-53BP1Related Survival of A549 and H1299 Human Lung Cancer Cells after Multifractionated Radiotherapy Demonstrated Different Response to Additional Acute X-ray Exposure. Int. J. Mol. Sci. (2020) 21; 3342. https://doi.org/doi:10.3390/ijms21093342

Vo Melnikova, S Bolshakov, C Walker and $\mathbf{H}$ Ananthaswamy Genomic alterations in spontaneous and carcinogen-induced murine melanoma cell lines. Oncogene (2004), 23; 23472356.

https://doi.org/10.1038/sj.onc.1207405

JC Mulloy, T Kislyakova, A Cereseto, L Casareto, A LoMonico, Fullen J, MV Lorenzi, A Cara, C Nicot, C Giam, G Franchini. Human T-cell lymphotropic/leukemia virus type 1 Tax abrogates p53-induced cell cycle arrest and apoptosis through its CREB/ATF functional domain. J Virol. (1998), 72(11); 8852-60.

https://doi.org/10.1128/JVI.72.1 1.88528860.1998.

M. Yu, J. Han, P. Cui, M. Dai, H. Li, J. Zhang, R. Xiu, Cisplatin up-regulates ICAM-1 expression in endothelial cell via a NF-kappaB dependent pathway. Cancer Sci. (2008), 99(2); 391-7. https://doi.org/ doi: 10.1111/j.13497006.2008.00696.x.

K. Raimonda, š. Indrè, D. Kristina, D. Rimantas, J. Sonata, Molecular features of doxorubicin-resistance development in colorectal cancer CX-1 cell line. Medicina. (2016), 52 (5); 298 - 306. https://doi.org/10.1016/j.medici.2016.09.0 03. 
M S Duxbury, H lto, E Benoit, T Waseem, S W Ashley, E E Whang. A Novel Role for Carcinoembryonic Antigen-Related Cell Adhesion Molecule 6 as a Determinant of Gemcitabine Chemoresistance in Pancreatic Adenocarcinoma Cells. Cancer Res (2004), 64(11); 3987-3993. https://doi.org/10.1158/0008-5472.CAN04-0424.

L. R. Palam, J. Gore, K. E. Craven et al., Integrated stress response is critical for gemcitabine resistance in pancreatic ductal adenocarcinoma. Cell Death and Disease (2015), 6; el e19132015.264 https://doi.org/doi:10.1038/cddis.

T. Cui, Y. Chen, L, Yang, T. Knosel, $O$, Huber, et al., The p53 target gene desmocollin 3 acts as a novel tumor suppressor through inhibiting EGFR/ERK pathway in human lung cancer. Carcinogenesis (2012) 33; 2326-2333.

SI. Núñez-Olvera, B. Chávez-Munguía, M. Terrones-Gurrola, et al. A novel protective role for microRNA-3135b in Golgi apparatus fragmentation induced by chemotherapy via GOLPH3/AKTI/mTOR axis in colorectal cancer cells. Scientific Reports. (2020), 10555. https://doi.org/10.1038/s41598-020-675500 .

\section{A. Sparks, S. Dayal, J. Das, P. Robertson, S, Menendez, M. Saville. The degradation of p53 and its major E3 ligase Mdm2 is differentially dependent on the proteasomal ubiquitin receptor $\mathrm{S} 5 \mathrm{a}$. Oncogene (2014), 33; 4685-4696. https://doi.org/10.1038/onc.2013.413.}

inhibitors: A novel therapy for cancer treatment. Biomedicine \& pharmacotherapy. (2019), 109; 484-492. https://doi.org/10.1016/j.biopha.2018.10.1 55. 